\title{
A conciliação aplicada pela Administração Pública Federal: uma análise do decreto 9.760/2019
}

rdai.com.br/index.php/rdai/article/view/424

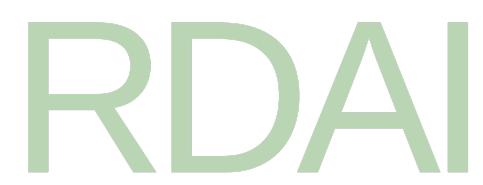

\section{Autores}

- Carlos Sérgio Gurgel da Silva Universidade do Estado do Rio Grande do Norte (Natal, Rio Grande do Norte, Brasil)

- José Albenes Bezerra Júnior Universidade Federal Rural do Semiárido (Mossoró, Rio Grande do Norte, Brasil)

\section{DOI:}

https://doi.org/10.48143/rdai.19.csgs

\section{Palavras-chave:}

Acesso à justiça, Administração Pública Federal, Conflitos ambientais, Conciliação, Núcleo de Conciliação Ambiental

\section{Resumo}

O presente artigo visa analisar a aplicação da conciliação pela Administração Pública nos conflitos ambientais sob a ótica do Decreto Federal 9.760/2019. Na primeira parte, é feita uma observância dos princípios ambientais e as infrações penais, com destaque aos princípios do poluidor-pagador, da precaução, da responsabilidade, da cooperação e do desenvolvimento sustentável. Na segunda parte, será feita uma análise do avanço normativo e o incentivo às práticas de conciliação, com ênfase ao acesso à justiça, a Resolução 125 do Conselho Nacional de Justiça e o Código de Processo Civil. Por fim, é feita uma análise do Decreto 9.760/2019, com destaque para os conflitos envolvendo a Administração Pública e a aplicação da conciliação aos conflitos ambientais. O artigo emprega uma metodologia bibliográfica e documental. As conclusões apontam para os avanços normativos relacionados ao emprego da conciliação nos conflitos que envolvem a Administração Pública Federal, contudo, ainda carece de efeitos práticos efetivos quanto ao Núcleo de Conciliação Ambiental.

\section{Biografia do Autor}

Carlos Sérgio Gurgel da Silva, Universidade do Estado do Rio Grande do Norte (Natal, Rio Grande do Norte, Brasil) 
Professor da Universidade do Estado do Rio Grande do Norte (Natal, Rio Grande do Norte, Brasil). Doutorado em Direito pela Universidade de Lisboa. Lattes:

[http://lattes.cnpq.br/6629152920412713_].

(iD 0000-0002-6053-4.73.9. | carlossergio@uern.br

\section{José Albenes Bezerra Júnior, Universidade Federal Rural do Semiárido (Mossoró, Rio Grande do Norte, Brasil)}

Professor na Universidade Federal Rural do Semiárido (Mossoró, Rio Grande do Norte, Brasil). Doutorado em Direito pela Universidade de Brasília. Professor da UFERS. $\underline{\text { ooo0-0002-75.98-885 }}$ | | albenes.junior@ufersa.edu.br

\section{Referências}

CALMON, Petrônio. Fundamentos da mediação e da conciliação. 2. ed. Brasília: Gazeta Jurídica, 2013.

CAPPELLETTI, Mauro; GARTH, Bryan. Acesso à justiça. Trad. Ellen Gracie Northfleet. Porto Alegre: Fabris Editor, 2002.

GRANZIERA, Maria Luiza Machado. Direito ambiental. São Paulo: Atlas, 2009.

LAGRASTA NETO, Caetano. Meios alternativos de solução de litígios. In: WALD, Arnoldo. Doutrinas Essenciais: arbitragem e mediação. São Paulo: Ed. RT, 2014. v. VI.

MANCUSO, Rodolfo de Camargo. A resolução dos conflitos e a função judicial no contemporâneo Estado de Direito. São Paulo: Ed. RT, 2015.

MENDONÇA, J. J. Florentino dos Santos. Acesso equitativo ao direito à justiça. São Paulo: Almedina, 2016.

MILARÉ, Édis; DA COSTA JR., Paulo José. Direito penal ambiental: comentários à Lei no 9.605/98 (LGL199875). Campinas: Millennium, 2002.

MILARÉ, Édis. Direito do ambiente. 9. ed. São Paulo: Ed. RT, 2014.

ONU. Declaração do Rio sobre Meio Ambiente e Desenvolvimento. Disponível em: [www.educadores.diaadia.pr.gov.br/arquivos/File/pdf/a21_florestas.pdf]. Acesso em: 19.11.2019.

ORGANIZAÇÃO DAS NAÇÕES UNIDAS. Comissão mundial sobre meio ambiente e desenvolvimento. Relatório Brundtland. Disponível em:

[https://edisciplinas.usp.br/pluginfile.php/4245128/mod resource/content $/ 3 /$ Nosso\%2 oFuturo\%20Comum.pdf]. Acesso em: 20.11.2019.

PINHO, Humberto Dalla Bernardina de; HALE, Durval; CABRAL, Trícia. O marco legal da mediação no Brasil. São Paulo: Atlas, 2015.

SIRVINSKAS, Luís Paulo. Manual de direito ambiental. 8. ed. São Paulo: Saraiva, 2010. 
SOUZA, Luciane Moessa de. Resolução de conflitos envolvendo o Poder Público: caminhos para uma consensualidade responsável e eficaz. In: GABBAY, Daniela Monteiro; TAKAHASHI, Bruno (Coord.). Justiça Federal: inovações nos mecanismos consensuais de solução de conflitos. Brasília: Gazeta Jurídica, 2014.

SPLENGER, Fabiana Marion. Teoria da ação comunicativa. In: Doutrinas Essenciais: arbitragem e mediação. São Paulo: Ed. RT, 2014. v. VI.

TRENNEPOHL, Terence. A proteção do meio ambiente na constituição federal. In: ELALI, André; ZARANZA, Evandro; SANTOS, Kallina Flor (Coord.). Direito corporativo: temas atuais. 10 anos André Elali Advogados. São Paulo: Quartier Latin, 2013.

TRENNEPOL, Terence. Manual de direito ambiental. 6. ed. São Paulo: Saraiva, 2018.

\section{Publicado}

2021-12-15

\section{Como Citar}

SILVA, C. S. G. da; BEZERRA JÚNIOR, J. A. . A conciliação aplicada pela Administração Pública Federal: uma análise do decreto 9.760/2019: The conciliation applied by the Federal Public Administration: an analysis of decree 9,760/2019. Revista de Direito Administrativo e Infraestrutura | RDAI, São Paulo: Thomson Reuters - Livraria RT, v. 5, n. 19, p. 133-156, 2021. DOI: 10.48143/rdai.19.csgs. Disponível em:

https://rdai.com.br/index.php/rdai/article/view/424. Acesso em: 7 fev. 2022.

\section{Edição}

\section{5‥19_(2021).}

\section{Seção}

Direito Administrativo: Direito administrativo sancionador

\section{Licença}

\section{(i) $(9)$}

Este trabalho está licenciado sob uma licença Creative Commons Attribution-

NonCommercial-NoDerivatives 4.0 International License.

\section{(CC BY-NC-ND).}

Este é um resumo (e não um substituto) da licença

Regras para publicação

Direitrizes Editoriais

Direitos e Deveres 
Errata e Retratação

Preservação e Plagiarismo

Revisão e Avaliação 
